\title{
The Politics of Governing African Urban Spaces
}

\author{
Edgar Pieterse
}

\begin{abstract}
Drawing on the author's direct experiences in urban policy formulation processes on various scales, this chapter makes a case for a more intimate reading and account of macro policy shifts that may hold the potential to advance transformative politics on the national and the urban scale. It argues that new policy concepts and frameworks can advance a more focused politics based on an analysis of the nature and terms of infrastructure investments and considers whether such investments are advancing a more inclusive, labour intensive and sustainable pattern of development in African cities and towns. The chapter asserts that urban governance policy discourses are now connecting urban investments and regulation with macroeconomic imperatives, which could lead to a greater awareness of urban governance within centres of state power. Structurally the chapter identifies examples of policy artefacts on the global, pan-African and national scales to demonstrate the shared potential for a new kind of transformative politics. Thereafter, the chapter sets out a potential methodological register to track, analyse and engage these processes on the urban scale in order to arrive at a propositional sensibility with regard to governing diverse spaces. It calls for a form of research and analysis that is not merely evaluative, after the fact, but rather positioned in the processes of unfolding. There are not enough of these kinds of scholarly accounts that can enrich and deepen debates about the politics and practice of multi-scalar urban governance reform in diverse African settings.
\end{abstract}

\section{Introduction}

My experiences in conducting urban policy advocacy and advisory work over the past three years are the entry point for this chapter, accumulated in the run-up to the bi-decennial convening of the United Nations Conferences on Housing-Habitat III. This chapter offers a reflection on why formal discursive shifts at both the global and the African level, about the territorial underpinnings of sustainable development, offer new opportunities to both imagine and instantiate a fresh politics on how urban areas are governed. It seeks to sidestep the typical approaches to the dynamics of multi-scalar urban

(C) EDGAR PIETERSE, 2018 | DOI:10.1163/9789004387942_003

This is an open access chapter distributed under the terms of the prevailing CC-BY-NC License at the time of publication. 
governance in Africa, which either provide neo-Marxian accounts of macroeconomic processes of neo-liberalisation (Miraftab, 2004; Obeng-Odoom, 2015; Ferguson 2011) or constructivist perspectives on the significance of everyday urbanism in shaping forms of rule, government and counter-governmentality (Bayat, 2010). This chapter relates to both strands in the literature but seeks to offer a closer reading of formal policy shifts with an eye to the kinds of critical politics that might emerge, building on the conceptual framework proposed by Scoones et al. (2015) and Swilling (2016).

The chapter starts by briefly rehearsing the various policy formulation processes I have been active in since 2015 to provide a contextual reference point for what follows. The following section traces some of the emblematic milestones in this policy reorientation with an eye to what it might mean for the imperative to rethink and remake multilevel governance arrangements animated by new normative policy imperatives such as 'infrastructure-led growth', closely linked to the macroeconomic imperative to achieve 'structural transformation'. These policy imperatives matter because they are forging and foregrounding a more explicit spatial articulation of macroeconomic policy. This articulation in turn instigates significant institutional reforms that announce, I believe, novel political opportunities for deep democracy and cultural citizenship (Pieterse, 2008; Mbembe, 2016). The second half of the chapter sets out a potential methodological register-in the broadest sense- to track, analyse and engage these processes on the urban scale in order to arrive at a propositional sensibility with regard to governing diverse spaces. It therefore calls for a form of research and analysis that is not merely evaluative after the fact, but is applied in the processes of unfolding. There is a dearth of these kinds of scholarly accounts that can enrich and deepen debates about the politics and practice of multi-scalar urban governance reform in diverse African settings.

This section situates my positioning in relation to the production of a number of policy artefacts on the pan-African and national (South Africa) scales during the last few years. Specifically, at the global level, I contributed to the technical research processes of UN-Habitat to formulate an overarching narrative about the state of the world's cities, with an eye to proposing comprehensive reforms to effect structural change. More specifically, I worked on Chapter Six of the World Cities Report 2016 (UN-Habitat, 2016), which deals with governance. Another global report that was published in 2016 was the GOLD IV report, 
by United Cities and Local Government (UCLG 2016). I collaborated with two colleagues to draft the synthesis and recommendations of this report, which explored the implications of the 2030 Agenda for Sustainable Development and its goals (SDGs) for different categories of territorial organisation: metropolitan areas, intermediary cities, regions, small towns and rural areas.

At the African level, I collaborated with colleagues at the African Centre for Cities (ACC) - an interdisciplinary research hub at the University of Cape Town-to craft a primer on what an African perspective might comprise regarding a new urban agenda for the world as governments were preparing for Habitat III, the United Nations convening on urbanisation that happens every twenty years. This work was published in early 2015. It was crafted to serve as a resource for governmental preparatory processes at national and sub-regional (e.g. West African, Southern African) levels to clarify the African perspective for Habitat III (UN Habitat and UNECA, 2015). Questions of governance, institutional design and politics were central to this paper, published under the auspices of UN-Habitat and the UN Economic Commission for Africa (UNECA). A second pan-African intervention took the form of a background research paper for the Organisation for Economic Cooperation and Development (OECD) and the African Development Bank (AfDB) as they were drafting the Africa Economic Outlook 2016, themed: Sustainable Cities and Structural Transformation (OECD, et al., 2016). The two Africa-focused policy papers had to confront the articulation of African specificities with emerging global discourses generated by the SDGS and the Paris Agreement, or Paris climate accord. This meant addressing systemic dysfunctionality as detailed by academic commentators, and the routine violation of rights and obligation (Davis, 2006; Myers, 2011; Swilling and Annecke, 2012).

Alongside this work on a global and African scale, I was deeply involved in national policy drafting processes in South Africa that sought to formulate the Integrated Urban Development Framework (RSA, 2016). This framework was a forerunner of National Urban Policies, or recognised tools toward global urban agendas as sanctified by the New Urban Agenda adopted at Habitat III. This experience gave me an opportunity to work through the discursive gymnastics required to articulate highly localised demands, histories and institutional imperatives with African and global discourses about urban governance, regulation and politics.

Lastly, and in anticipation of criticisms that I am simply the 'bagman' for what academics call free-floating or 'travelling' discourses (Harris and Moore, 2013), during this time I also worked closely with a social movement called the Social Justice Coalition (SJC). The SJC is operative around safety and sanitation 
issues in areas of Khayelitsha, one of the largest suburbs of Cape Town. ${ }^{1}$ Strictly speaking, this was not conventional research but rather a process of mutual socialisation and exchange. I spent time with a cross-section of the leadership of the SJC, on a periodic basis, to creatively explore dilemmas of strategy and tactics, drawing on social history methods in a focus group setting. In return, I offered my experience and knowledge of comparable social movement practices in other urban settings of the world, as well as earlier periods of social struggle in Cape Town. These intimate conversations were profoundly important as an anchoring device while I was plying my policy craft on these other scales of policy politics.

One of the insights gained over the course of this work was into the ways in which the political/policy ground on questions of urbanisation in subSaharan Africa had shifted from only a few years before this engagement. In 2014, Sue Parnell and I published the edited volume Africa's Urban Revolution; many chapters in that volume confirm the long-standing lament about the anti-urban bias practised by most African governments, manifested in mired devolution efforts combined with futile anti-migration policies (UN-Habitat, 2014). However, over only a few years there has been a sea change at various levels of formal governance across the continent. Most significantly, at a panAfrican level, the African Union, UNECA and the AfDB have all been driving a much more aggressive line around the imperative to rethink, remake and reinvest multilevel governance arrangements to improve the prospects of 'structural economic transformation' and inclusive growth. These gestures towards an African-centred perspective on inclusive modernisation rest on an acknowledgement of urbanisation as evident in Agenda 2063 - the signature political programme and ideological frame of the African Union, initiated in 2013 in Addis Ababa on the occasion of the 5oth anniversary of the establishment of the Organisation of African Unity (African Union, 2014). This 5oth milestone informed the 50-year horizon of the revitalised pan-African vision as reflected in the designator: Agenda 2063.

Embedded in this new policy discourse is an unmistakable recognition that unless a stronger territorial or spatial understanding begins to drive routine processes of infrastructure investment and economic development, most African countries will remain low-income and marginal in global value chains (UNECA, 2015; 2017). Furthermore, it is recognised that the imperative to coordinate, sequence and calibrate disparate investments in highly

1 See the Social Justice Coalition website http://www.sjc.org.za (accessed on 18 April 2018). 
complex and volatile systems requires a territorial proximity, for which the traditional model of national-centric planning and management is not well suited.

\section{3}

\section{Major Discursive Shifts}

The 2030 Agenda for Sustainable Development (United Nations 2015), as embodied in the 17 sustainable development goals (SDGs), is highly significant and reflects the culmination of at least two decades of sustained human rights struggles to push back on the narrow economistic precepts of neo-liberal managerialism. ${ }^{2}$ For example, there is an explicit recognition that growing intra- and inter-country inequality is a major impediment to inclusivity. This is a profound break with the reformist 'poverty reduction' orientation of the Millennium Development Goals of 2000. The SDGs also acknowledge the environmental limits of the dominant growth model that remains the de facto reference point for governments and companies. Thus, there is a strong push to mainstream the work and perspective of the United Nations Environment Programme (UNEP) on sustainable production and consumption, linked to a separate set of goals on changing the carbon intensity and resource consumption patterns that underpin global value chains across all domains of economic activity. In other words, in the SDGs there is a mainstreaming of the long-established political claims and policy proposals to internalise negative environmental and social costs, opening up a line of politics to build a broad-based front against extractive and exploitative capitalist processes. It is precisely these ambitions that have reinforced a more popular discourse and imagination about post-capitalist futures and trajectories (Mason, 2015; Srnicek and Williams, 2015). Lastly, the sDGs also recognise the importance

2 It is important to keep in mind that since 1990, with the publication of the first Human Development Report by UNDP, there has been a fierce ideological contestation between the Bretton Woods institutions and the United Nations. Fundamentally it turned on Amartya Sen's human capabilities approach versus a narrow neoclassical perspective on market-led development. After Rio+2o, the green economic perspective, riding on the momentum of the environmental limits work of the IPCC, was able to broaden the mainstream debates to incorporate various shades of green analysis (Swilling and Annecke, 2012). Throughout these processes, the human rights struggle of social movements and watchdog bodies have been instrumental in keeping up the political pressure necessary for mainstream arguments to shift away from crass neo-liberalism to a broader, more heterodox perspective as manifest in the SDGs and the Paris Climate Accord of 2015. 
of sustainable urbanisation as a precondition for a more green and inclusive economic patterning of development. This is a major departure from the aspatial and implicitly anti-urban orientation of the MDGs (Parnell, 2016) and has created room for a pointed argument that the SDGs must be 'localised' - that is to say, driven from the grassroots by municipalities and citizens' movementsto find resonance and sustained traction in diverse contexts (Pieterse, et al. 2017).

A number of broader dynamics made it possible for the SDGs to break with the welfarist reformism of the MDGs. Firstly, the damaging environmental impacts of existing economic globalisation processes have been argued convincingly through climate change evidence and its calculation-driven discourse, creating an opening for the broader sustainable development perspective of yonder to stage a comeback after being unable to substantively shift the economist reference points of international and national developmentalism (Scoones et al., 2015). Secondly, the exclusionary and alienating aspects of neoliberal globalism were made evident through the lingering effects of youth unemployment and political volatility across many OECD countries, especially in southern Europe, linked to the decentralised impacts of terrorist violence related to so-called alienated youth. Populist ideologues on both the left and the right stepped into this disjuncture, unsettling traditional centrist parties (and coalitions) across the OECD world, but also deeply entrenched political parties that have been in power since independence in many African countries. The post-2008 era spelled political uncertainty, volatility and changing public attitudes towards incumbent political parties, undermining the hegemony of economic globalists and the political parties who grew fat off those ideological regimes (Castells and Himanen, 2014).

These broader trends played out in interesting ways in much of sub-Saharan Africa. The 'boosterism' narrative that Africa's economic time had come, which took hold and flourished post 2000, was starting to experience strain. GDP growth rates started to slow and stagnate, and substantial investment gaps remained. Two structural breaks on sustained and high economic growth were identified across development and private sector think tanks: limited and inefficient infrastructure and weak governance and regulatory practices that constituted systemic risk for large-scale investment (McKinsey Global Institute, 2016; PwC, 2015). Of course, these two dynamics are inextricably linked. It is against this background that my focus turns to the announcement and promotion of Agenda 2063. In keeping with the nature of these aspirational and norm-setting policy frameworks, Agenda 2063 envisages a profoundly transformed Continent, people and economy: 'an integrated, prosperous and peaceful Africa, driven by its own citizens and representing a dynamic force 
in the international arena' (African Union, 2015, 1). This vision is meant to be realised through a highly focused, strongly normative and popular agenda that is cognisant of the importance of

... mobilization of the people and their ownership of continental programmes at the core; the principle of self-reliance and Africa financing its own development; the importance of capable, inclusive and accountable states and institutions at all levels and in all spheres; the critical role of Regional Economic Communities as building blocks for continental unity.

African Union, 2015, 1

This assertion hints at the seductive yearning for a uniquely African social solidarity, rooted in long-standing (perhaps imagined?) cultural values and practices that have endured despite the horrors of colonialism, ready to be mobilised for a modernised version of what Africa was always meant to be: united 'to realize its Renaissance'. It would be the easiest thing in the world to poke holes in the kitsch fabric of this obvious fiction. But that would be to miss the point about the importance of animating narratives that create a semblance of a shared footing in order to have certain kinds of political conversations that may, or may not, lead to coordinated action across profound differences and disagreements. I will return to the notion of shared narratives and the work they do in the fabrication of political and public spaces.

Notably, Agenda 2063 is certainly a product of its time. At least since the MDGs there has been an unmistakable adoption of performance management rhetoric and planning across most development frameworks and agreements. For example, the 2030 Agenda for Sustainable Development has 17 goals and 169 targets that all nation states will be measured against on an annual basis in anticipation of achievements by 2030. Similarly, Agenda 2063 must be read alongside the 'First Ten Year Implementation Plan 2014-2023', published by the African Union. This 140-page compendium of goals, targets, indicators and so forth set out in meticulous detail—even if some are wildly optimistic - how the seven aspirations (see Box 1) of Agenda 2063 will be realised. This is not the occasion to delve into the function of these kinds of policy artefacts, but it is important to recognise their existence and how they might provide a staging ground for a nuanced politics of critique, collaboration, learning and experimentation and the forging of novel coalitions across sectors and scales. These artefacts are not meant to be taken literally. They are discursive mechanisms aimed at instilling confidence and purpose in a sea of uncertainty and uncontrollable factors that will scupper the most well-laid plans (Roe, 1993). 


\section{Box 1: Aspirations of Agenda 2063}

1. A prosperous Africa based on inclusive growth and sustainable development

2. An integrated continent, politically united, based on the ideals of Pan-Africanism and the vision of Africa's renaissance

3. An Africa of good governance, democracy, respect for human rights, justice, and the rule of law

4. A peaceful and secure Africa

5. An Africa with strong cultural identity, common heritage, values, and ethics

6. An Africa whose development is people-driven, relying on the potential of African people, especially its women and youth, and caring for children

7. Africa as a strong, united, and influential global player and partner.

Source: African Union (2015)

One of the most important impacts of Agenda 2063 is that it has made a clearing for a more grounded and politically astute macroeconomic policy discussion under the sign of the concept of structural transformation (UNECA, 2015). This concept represents an attempt by African economists to confront the deep-seated legacies of colonial exploitation and the ways in which these laid the tracks for the asymmetrical incorporation of African economies into globalisation. It then follows that extraordinary policy focus and discipline is required to deploy macroeconomic and fiscal levers of the state to escape historical traps of dependency in favour of a more dynamic and inclusive trajectory. However, this cannot be done without leveraging the collective power of supranational regions in Africa and, ultimately, the African continent as a single economic organism characterised by the 'Free movement of people, goods, capital and services to increase trade and investment among countries' (African Union, 2015). If Agenda 2063 does nothing else but give genuine impetus to a single economic and labour market for Africa, it can be regarded a success. Furthermore, structural transformation is linked to a more explicit consideration of space and territoriality in meeting the lofty aspirations of the African Union and its member states. The rapidly expanding work from UNECA $(2015,2016,2017)$ has been the most significant body of development thought to substantiate the political, policy and regulatory implications of the lofty ideals of Agenda 2063. 


\section{Box 2: Structural Transformation}

Structural transformation is the defining characteristic of the development process. It entails the allocation of resources-especially new investments - from low- to high-productivity activities within and across sectors, especially the agriculture, industry and services sectors. [...] Four quite relentless and interrelated processes define the structural transformation process: (a) a declining share of agriculture in gross domestic product (GDP) and employment; (b) the rapid process of urbanization as people migrate from rural to urban areas; (c) the rise of a modern industrial and service economy; and (d) a demographic transition from high to low rates of births and deaths. The final outcome of structural transformation is an economy and society in which agriculture as an economic activity has no distinguishing characteristics from other sectors, at least in terms of the productivity of labour and capital or the location of poverty.

\section{Source: UNECA (2015)}

UNECA has produced a series of development reports on various dimensions of structural transformation. This output ranges from an analysis of trade policy (UNECA, 2015) to an exploration of why an explicit green economic approach is the most promising for realising the ideals of structural transformation (UNE$\mathrm{CA}, 2016)$, and the most recent focus on the connections between urbanisation and structural transformation (UNECA, 2017). It is this last report that I draw upon to illustrate the policy narrative that UNECA is driving, which is achieving significant traction with key infrastructure financing institutions such as the AfDB, the World Bank, various Chinese banks and the Development Bank of Southern Africa (DBSA).

But first, a few words on the policy meaning of structural transformation. At its core, structural transformation denotes processes to 'shift labour out of lowproductivity agriculture into higher-productivity manufacturing and modern services' (UNECA, 2017, 20). Across most of sub-Saharan Africa, this shift is not occurring fast enough and many countries display an economic structure almost unchanged since the postcolonial era (see Figure 2.1). Thus, the relative shares of agriculture, industry and services have remained more or less the same-with the exception of manufacturing as a component of industry, which has actually declined since 1960 in relative terms. These patterns persist despite a dramatic expansion of the labour force and educational improvements, particularly over the past two decades. Large-scale, labour intensive and productive industrialisation is not on the cards for most African economies, a situation that leaves them marginal and vulnerable in an increasingly 


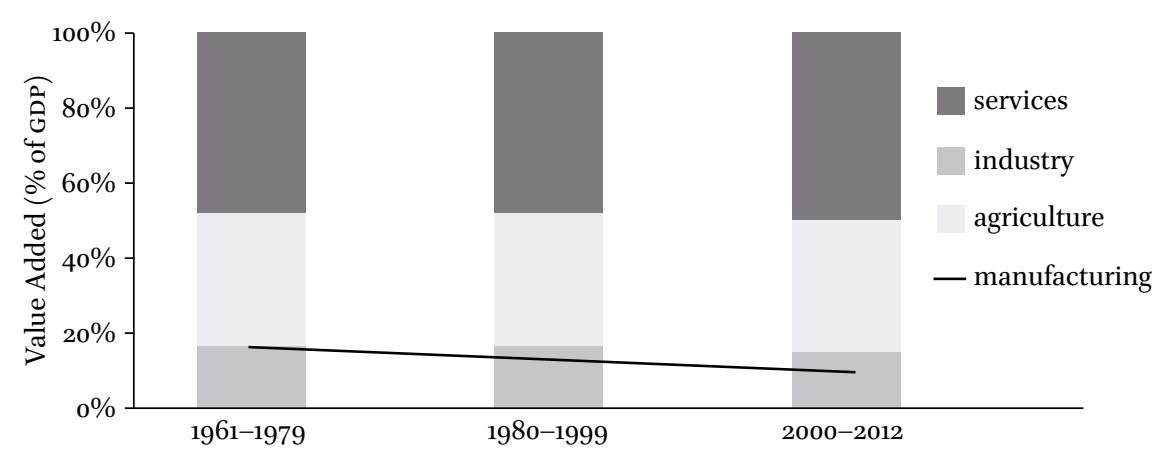

FIGURE 2.1 GDP composition by sector, Africa, 1961-2012.

SOURCE: UNECA $(2015,47)$

integrated global economy and, most importantly, unable to absorb new entrants into the formal labour market.

Given the youthful demographics of sub-Saharan Africa and the persistence of high fertility rates, this is a recipe for economic and political ruin-especially as young people are more prone to participate in oppositional protests and disruption, dynamics that are seemingly exacerbated by the proliferation of mobile digital technologies (Honwana, 2012). This speaks to the centrality of the structural transformation discourse across pan-African political, development and financing institutions. It is also a discourse that can enrol and animate the private sector and civic groups keen on fostering a politics of inclusion and voice, especially for youth. It even resonates with proponents of the informal economy because these practices are seen as evidence of a lack of structural transformation and therefore as ideal agents to be supported in order to deepen industrialisation and productivity. However, the dimension of the UNECA outlook that is most striking is the recent embracing of a spatial and territorial perspective in thinking through the governance preconditions for reorienting macroeconomic and infrastructure policies to derail the low-industrial, pathdependent track that most African countries find themselves on.

Earlier in 2017, UNECA launched its flagship annual development report, themed Urbanization and Industrialisation. It unpacks with refreshing candour the connections between African urbanisation and economic performance:

African cities thus face low productivity, tepid job creation, high informality, huge infrastructure and service gaps, weak linkages with rural areas, high levels of informality, increasing inequalities, growing environmental damage and vulnerability to climate change and weak institutional systems and capacities. Unless resolved, these impediments will undermine Africa's urban potential for structural transformation. [...] The challenge 
confronting Africa is thus to accelerate structural transformation by harnessing the rapid urban transition to promote economic diversification, with a special focus on industrialization that will create jobs, enhance access to basic services and reduce inequality and poverty.

UNECA, 2017, 20

The second part of this position is based on an assumption that as urbanisation intensifies the growing population represents crucial potential markets for goods, services and especially infrastructure systems that will have to conduct the generation and circulation of economic value. Thus, for UNECA, the key to structural transformation lies in territorial and infrastructure planning because global value chains have particular geographies and there is policy scope to rethink and re-engineer these geographies through thoughtful and anticipatory infrastructure planning in order to foster dynamic, interdependent and differentiated national and (subnational) regional economies. In the previous report in 2016, UNECA goes further and argues that territorial infrastructure planning can disrupt uneven development and urban primacy, as well as catalyse a simultaneous transition to a green economy in terms of the underlying technologies that will shape energy, mobility, water and ICT investments (UNECA, 2016).

Significantly, the Urbanization and Industrialization report goes further than infrastructure and foregrounds the problematic urban form (spatial structure) of many African cities, which not only reinforces social segregation but also represents a substantial cost for urban livelihoods and businesses. However, the report not only argues for refined macroeconomic policy but also for drastic intergovernmental institutional reconfiguration so that local actors who are most knowledgeable about local conditions can do the frontline work of detailed industrial and spatial policy design, effectively providing a renewed argument for the substantive devolution of powers, functions and financial authority. This is important because evidence from many sub-Saharan African countries demonstrates that devolution reforms have essentially become stuck for at least the past two decades, with cases of re-centralisation when opposition political parties were able to get a foothold in municipal governance (Resnick, 2012).

UNECA can be this bullish in its policy arguments because of important shifts that have taken place at the African Union level. In order to prepare for an African regional perspective on a new urban agenda deliberated at Habitat III in 2016, the African Union established a new political subcommittee on Urban Development and Human Settlements of the African Union Specialized Technical Committee on Public Service, Local Government, Urban Development and Decentralization. This technical committee was itself a novel structure when it was first convened in 2014. The work of this subcommittee culminated in the adoption of the Common African Position on the Third 
United Nations Conference on Housing and Sustainable Urban Development, in February 2016. The Common Position sets out a number of approaches that set the stage for the Africa Economic Outlook 2016 and UNECA's publication, Urbanization and Industrialization. These overlapping and mutually reinforcing macro policy frameworks are indeed unprecedented and represent, if read carefully, a radically different institutional and political landscape for future governance dynamics as territorial considerations become interlinked with macroeconomic decisions and infrastructure investment regimes. In the second half of this chapter, I delineate what this political landscape contains in order to make a speculative argument for 'translational research' that can document, critique and extend multi-scalar politics.

In the wake of the SDGs, the Paris Climate Accord and the New Urban Agenda, the formal policy reference points of an ideal multilevel governance approach have shifted. It is now recognised that multilevel institutional configurations must be defined in relation to a macroeconomic policy ideal that seeks to accelerate industrialisation. This ideal is based on a locally defined set of economic strategies that seek to intervene in the value chains of key economic sectors that depend on expanding urban populations. It is further accepted that the infrastructure investments required to optimise industrialisation and urban efficiencies should be made and coordinated by local actors who understand the micro dynamics of the territorial economies that should anchor economic diversification. It is further asserted that these infrastructure investments should not only drive industrialisation but also create a platform for a transition to a low-carbon and resource-efficient economic structure that optimises labour absorption. These are significant discursive shifts that raise daunting questions about how one can change the predominant dynamics and values of pre-existing governance cultures.

Three weighty problems present themselves. First, most African countries and cities are marked by infrastructural and spatial path dependency dynamics that are notoriously difficult to change. In other words, the regimes of infrastructure technological design, operations and management are crystallised around a deeply entrenched set of vested interests. Since infrastructure investments have long lead times, what is currently on the books will remain a dominant structuring force for at least the next five to ten years. Second, technical path dependency is reinforced by an even more pernicious dynamic of institutional inertia. There is a large body of scholarship on the dysfunctional nature of public sector bureaucracies in many African countries (Rakodi, 2002; 
Stren, 2014). Typically, the public sector remained cast in the mould of colonial administrations, especially in terms of hierarchical power relations embedded in command-and-control decision-making. This was a system that proved useful to entrench a new postcolonial administrative elite that was intimately entwined with the political party machines that overdetermined the economy, politics and administrative functioning. These dynamics were further entrenched and perverted when new public administration tools around privatisation, corporatisation, partnerships and performance management were overlaid in an instrumentalised fashion. Instead of promoting greater responsiveness to the needs and demands of citizens, bureaucratic power became more intensified and opaque but draped in a language of accountability and performance, fuelling deep-seated mistrust and public cynicism. Rents that politically connected actors are able to extract rely on this institutional dysfunction. Third, in most African contexts dominant ruling political parties overdetermine every aspect of public priority setting and resource allocation. This is such a pervasive fact of life that most actors and citizens simply take it as a given and this power is derived from keeping the system as is.

The culturally specific manifestation of these dynamics needs to be made legible through careful research and analysis. Three conceptual entry points are relevant for this research work: narrative, ritual and deal-making. The narrative dimension of governance refers to where dominant circulating discourses are deployed to fashion and reproduce the necessary fictions (or facts) of rule. These are large, muscular and often masculine normative frames such as patriotism, pan-Africanism, empowerment, Ubuntu, and the like. These narratives stabilise nation building and forge the basis of the legitimacy and authority of ruling elites. Importantly, such narratives feed off and blend in with popular cultural currents that congeal the meanings of citizenship and political attachment. It is arguable that the highly successful Pentecostal mega churches that are mushrooming across African cities in all linguistic regions manifest a similar dynamic (Adesoji, 2016; Rakodi, 2014). It is unhelpful to dismiss the popular cultural beliefs and practices of this order as false consciousness or deceit. These narratives endure and reinvent themselves because they function in highly subtle and resonant ways as public affects (Amin and Thrift, 2013; Connolly, 2014). They are best dislodged and problematised through competing narratives that have a stronger affective pull.

The ritual dimension denotes the embodied institutional scripts that flow from these narrative frames and allow for a certain kind of translation into administrative practices and effects. It is in rituals that the performative dimensions of politics come to the fore. In a context of relatively limited resources due to small tax bases and highly truncated systems of patronage, rituals are 
even more exaggerated and achieve a life force and dynamism of their own. Generally, political party cultures, hierarchies, decision-making systems and informal networks shape these, but they are always interwoven with formal deliberative governmental procedures in both the legislature and the executive and administrative components of the state. Arguably, party dominant bureaucracies take their cue from these ritualised practices to establish a set of administrative systems and practices that quickly manifest in unique rituals that must be mastered if one is to get anything done or enabled. These rituals can vary widely, ranging from militarist efficiency to the extravagantly baroque (Mbembe, 2001). It is not possible to move economic or political agendas forward without understanding and engaging with these performative dimensions of statehood. Furthermore, non-state cultural reference points, such as religious affiliations or hometown networks, are vital to the maintenance and reproduction of these rituals.

Deal-making is another dimension of the unravelling and remaking of multilevel governance. The understanding of framing narratives and the ritual of performative politics are helpful to decipher the profound gap between formal state rhetoric and practice, and how such practices relate back to party dynamics and elite functioning. However, they are always intertwined with a profound pragmatism to cut deals in order to navigate opaque 'rules of the game' and keep resources flowing. Deal-making happens behind the translucent screens of narrative and ritual. In other words, if actors who want to advance an alternative, more progressive politics fail to read the prevailing narratives and their functioning, along with the rituals of public administration, they will simply not be effective in shaping narratives or destabilising practices that reproduce the status quo. This brings this chapter to its penultimate thematic: what kind of politics can be imagined and institutionalised to ensure that the progressive normative ambitions of Agenda 2063 and the trope of green structural transformation can in fact be achieved?

\section{$5 \quad$ Reimagining Power Through Infrastructural Politics}

The most potent politics aggregates around infrastructure (Larkin, 2013; Swilling, 2013). Since infrastructure deficits and malfunctioning constitutes the largest brake on sustained economic growth and accumulation, it attracts an inordinate amount of political and technical attention, not least from international actors on the financing side of the development industry (Pieterse and Hyman, 2014). The downstream effects of infrastructure malfunction are also most likely to trigger social dissent and protest and, in this sense, always carry a 
political charge. The planning and financing of infrastructure falls to the most powerful centres of the state: ministries of finance, economic development, and infrastructure, and typically the presidency.

These actors are also the primary targets of pan-African norm-setting forums and national commitment, which does, in theory, create leverage in terms of holding them accountable and advocating, at the policy narrative level, around adopted or professed norms. For example, the assertions and commitments embedded in the Common African Position on a New Urban Agenda adopted in February 2016 are highly consistent with the recommendations from UNECA's work discussed earlier. Since the senior ministries in the state are involved and a number of bold and clear policy propositions have been accepted, it is conceivable that a radical, transformative platform can be constructed to shift the trajectory of the country and the city. However, this does depend on a savvy coalition of actors from diverse sectors of civil society who are able to explicitly connect local demands for more transparent and equitable infrastructure investments and democratic decentralisation reforms with the normative imperatives of these pan-African frameworks. Increasingly, the African Union (AU) and various UN bodies that deal with these questions are creating spaces for civil society actors to engage, monitor implementation and apply pressure. If these opportunities are exploited by various civil society networks and movements that work on social justice and democratisation, this potential can be realised (Miller et al., 2006).

Significantly, infrastructure systems also reveal most clearly the coexistence of formal and informal systems of social and economic reproduction. For example, given the low levels of baseload energy infrastructure, the majority of African households are responsible for their own micro infrastructure solutions. This is typically expensive and inefficient but energy-poor households find a way (Jaglin, 2014). Similar scenarios pertain to water access, sanitation, transport, housing and so forth. A rich and helpful academic research agenda has sprung up to make legible and comprehend these hybrid sociotechnical systems that underpin the functioning of African cities and communities. In the case of energy, most urban households who live in slum conditions rely on biomass, which is not particularly efficient and often detrimental in environmental health terms. Similarly, most of the (public) transport infrastructureminibus taxis - is privately owned and operates in a grey zone of semi-formality. Likewise, neighbourhood-based social enterprises and/or cooperatives organise waste management and sanitation disposal (Thieme, 2017). The point is that any future evolution of these hybrid infrastructures must engage with the de facto hybrid functioning of these systems and allow for a contextually defined transition to more effective, integrated and formal structures over time, with an acceptance that multiple systems with different rhythms and 
institutional forms will have to coexist for the foreseeable future. It is indeed these system adaptions that can undergird the green economy, as envisaged by UNECA (2016) and others (Cartwright, 2015; Hyman and Pieterse, 2017; OECD et al., 2016; Pieterse and Hyman, 2014).

Notably, the expansion of infrastructure investment and the concomitant planning of future systems that are more inclusive and adaptive will require a change to multilevel governance systems. It is in this imperative that the strongest potential for a transformative politics lies. Why? Infrastructure priorities defined in terms of the imperatives of access, green economic transitions and basic urban efficiency demand a more coordinated, sequenced and integrated approach to infrastructure planning, investment, delivery, maintenance and repair. And since any infrastructure response will have to acknowledge and incorporate de facto hybrid systems of functioning, it will also require careful and sustained engagement with informal providers and intermediaries. The imperatives of coordination and incorporation demand a localised institutional framework for infrastructure planning and management, especially as the complexity of variegated demands in major urban hubs intensifies and international investors demand localised institutional capacity and accountability. These exogenous factors conspire to create novel political openings and opportunities for progressive urban actors wishing to animate new terms of engagement and urban incorporation. However, this implies a savvy and nimble political sensibility and capacity. In order to clarify and advance what this imaginary might add up to, I explore a few conceptual diagrams that can anchor localised strategies.

\section{Triangulating Dimensions of Governance, Forms of Power, and Political Settlement}

Earlier in this chapter, I proposed the utility of distinguishing between three nested dimensions of contemporary governance: narrative, ritual and dealmaking. In order to get a purchase on the strategic opportunity structure for the kind of transformational infrastructure politics of green growth and livelihood enhancement, it is important to adopt a sociological analysis of power in the state and its cultural embedding in society. The applied development policy literature (Pettit, 2013) that distinguishes between visible, invisible and hidden power provides a useful prism without suggesting that it exhausts the complex flows and dynamics of power and counter-power in the heterotopic sense. If we take one step further and triangulate these two aspects with another pragmatist framework to characterise the dominant features of political economy factors that shape macro politics and its intricate folds, the work on 
political settlements by Kelsall (2016) represented as a 3-D space offers some useful insights. I will briefly expound on these two frameworks before making some cursory remarks on how they can enrich a transformational urban politics.

The first framework is the useful typology on visible, invisible and hidden power proposed by Pettit (2013) and Gaventa (2013). Visible power is the manifest capacity of actors in formal decision-making bodies and public spaces to present and advance their interests, (ideological) perspective and priorities. In substantially democratic institutions, these power contests are regulated by legally enshrined principles and tend to fix public attention because they embody what is deemed 'proper' politics worthy of media attention. Much government, donor and civil society energy is invested in participatory governance instruments that target formal decision-making arenas. On the urban scale, this would typically be either the municipal council or a host of ancillary participatory mechanisms that seek to effect consultation around council decisions or various kinds of municipal planning processes. The assumption is that there is a direct connection between what is being discussed in these chambers and plans, and the routine functioning of local state institutions.

By contrast, hidden power as a concept in this framework illuminates the ways in which formal political and policy deliberative processes and forums are not a level playing field - the ways in which numerous voices and interests are systematically excluded from the debate. Hidden power explains how official political and policy arenas are constructed and hemmed by specific discourses (Flyvbjerg, 2001) and associated institutional habits. These discourses incorporate assumptions about how to frame an issue, what is 'sayable' and what is politically or culturally considered taboo (Healey, 2004; Pieterse, 2005). Hidden power is effective when the media or citizens do not question the very assumptions that structure a public policy issue.

Hidden power works effectively because it is culturally underpinned by invisible power, which stems from subjectivity_or, how a person understands and enacts a sense of self as an expression of self-esteem, confidence, selfworth, dignity and corporeality. Theoretically hidden power draws on the overlapping insights of Gyatry Spivak, Michel Foucault, Paulo Freire and Steve Biko. In highly stratified, patriarchal and unequal societies, those at the bottom of the privilege pile are systematically devalued and considered inferior, in part due to their material and educational deficits and in other senses due to their membership of 'inferior' classes or castes. Thus, invisible power 'involves the ways in which awareness of one's rights and interests are hidden through the adoption of dominating ideologies, values and forms of behavior by relatively powerless groups themselves. Sometimes this is also referred to as the "internalisation of powerlessness" in a way that affects the awareness and 
consciousness of potential issues and conflicts, even by those directly affected' (Gaventa, 2013). In undemocratic and authoritarian societies, political elites and dominant groups actively reproduce these cultural systems of devaluation and social exclusion because they reinforce their hold on power and resources. In an era in which religious ideologies, intertwined with accumulation practices and political sway, exercise increasing influence over the affairs of the state and the economy, various cultural belief systems tend to reinforce invisible power (Naim, 2013).

Moving on from forms of power, it is instructive to consider the intervention by Kelsall (2016) who created an analytical tool to generate a more precise and contextually specific account of dynamics from a given political settlement and how it structures the opportunity space for visible and invisible power. The tool is structured along three axes to create a cube space of triangulated description (see Figure 2.2). The first axis denotes the nature of horizontal

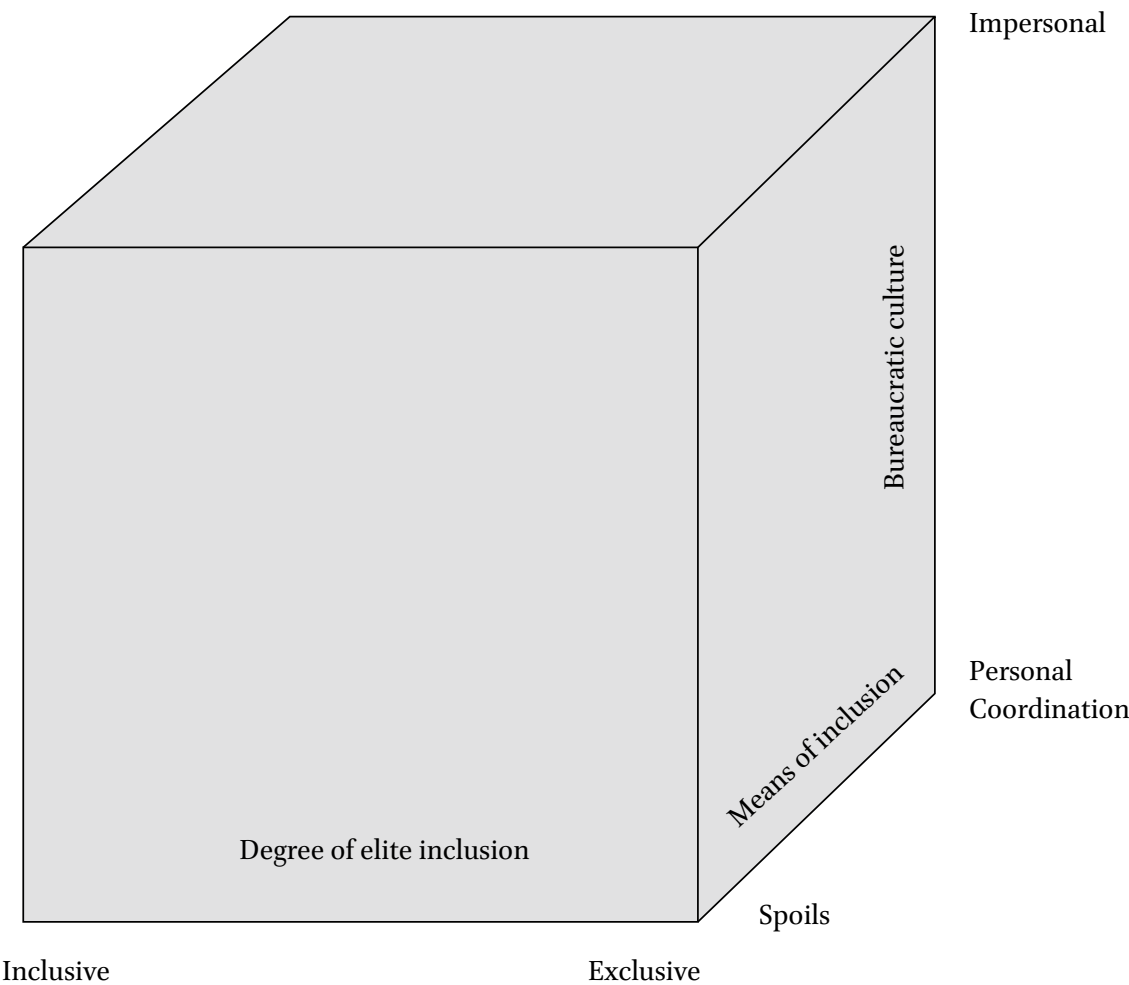

FIGURE 2.2 The political settlements 3-D space. SOURCE: KELSALL $(2016,3)$ 
elite incorporation. It simply addresses whether the majority of elites accept the political settlement and have given up on the option of using violence to disrupt or end it. If many elites maintain the option of violence, the axis will indicate exclusion.

The second axis addresses why elites are willing to accept the political settlement: are they 'in' because they get a share of the 'spoils' or are they persuaded by a larger common purpose that flows from a broader narrative of nation building, or developmental statehood, and so forth, which create a basis for the more inclusive structuring of institutions? Of course, in most places it would be a combination of these kinds of discourses interwoven with some measure of sharing the spoils. Returning to the earlier points about the emergence of qualitatively different developmental narratives about green industrialisation and employment being the core of the 'African Renaissance' or Agenda 2063 , it becomes clearer how these signifiers can potentially be put to work to deepen the ideological and symbolic repertoire of local political actors who want to embrace a pan-African cosmopolitanism. I would go so far as to say that the progressive aspirations of Agenda 2063 that pertain to the entrenching of 'democratic values, cultural practices, universal principles of human rights, gender equality, justice and the rule of law' and the consolidation of 'capable institutions and transformative leadership' are norms worth supporting with vigour as a means of bolstering the cultural appeal of a broader non-personal political aspiration (African Union, 2015). This also speaks to the third axis of the framework.

The third axis denotes the nature of the bureaucracy or public sector. In its ideal form, it is predominantly propelled by impersonal principles of ruledriven fairness, administrative justice and meritocracy, or is based on personalised systems of exchange that manifest as rent seeking, patronage and clientelism. There is a rich literature on the ways in which these lumpy concepts fail to account for the micro negotiations that can see outcomes whereby forms of patronage and clientelism can in fact produce inclusionary outcomes, especially when non-elites are adept at playing and subverting the 'rules of the game' (Duncan and Williams, 2012; Kelsall, 2016; Platteau, 2004). These accounts enrich this pragmatist frame, they do not obviate it.

In summary, there is a significant deepening of pan-African developmentalist discourses that connect macro outcomes such as inclusive growth and environmental sustainability with a stronger territorial imagination about how states need to restructure their internal multilevel systems to become more effective, popular and inclusive. This can, and should, be seized by progressive actors and scholars who wish to instantiate a more radical, democratic and 
inclusive urban politics. However, to be effective in this regard it is important to deploy research and analysis to build a much more rounded and fine-grained account of the status quo and why it remains stubbornly impervious to successive waves of policy reform. Such a research effort demands a more sober and direct account of the political opportunity structure if it is to progressively instantiate these emerging developmentalist discourses. This section of the chapter suggests the triangulation of three analytical prisms. This begins with a broader analysis of the nature of the political operating field through the adapted use of Kelsall's 3-D cube, which typifies elite incorporation, culture and bureaucratic disposition. The crude accounting that such a step yields can then be nuanced by isolating the ways in which overarching narratives of nationhood and state-building create a series of rationalities for specific rituals of state performance, which in turn provides a canopy for a wide range of grounded micro practices of deal-making within which ordinary people and their various intermediating social networks are always hard at work to capitalise on deals or renegotiate them. However, to establish a truly grounded reading of the cultural terms of these processes, it is necessary to overlay the analysis with an account of how visible, hidden and invisible power dynamics work in practice. This requires fine-grained and possibly 'embedded' research to account for the practices, rationalities and dynamics of public institutions charged with interpreting and enacting broader normative visions. In the last section of this chapter, by way of a conclusion, I make a case for sustained social science research to populate the triangulation imperatives with sound data and analysis. However, this is not enough; we need to think of the role of research as integral to the larger imperatives of fostering new institutional systems of governance, management and rule that strengthen national imperatives to discharge coordination and alignment. At the same time, we need to recognise that alternative local governance and policy processes cannot emerge unless they are connected to experiments, which can generate novel ways of planning, structuring, investing in and running sustainable infrastructures that contribute directly to economic empowerment and socio-spatial inclusion.

At the risk of frustrating the reader, I will not elaborate in any detail upon what this experimental research milieu entails but will simply deploy a diagrammatic overview of its recursive logics (Figure 2.3). The entry point is the fundamental task of academic research: critical thought. Such thought is conventionally 


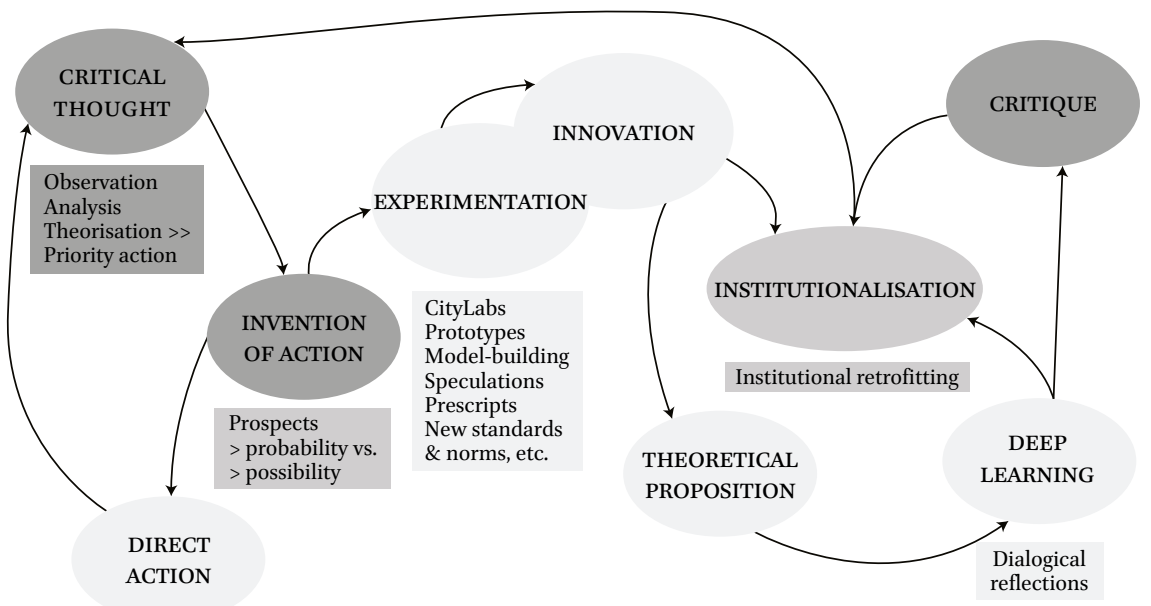

FIGURE 2.3 Dialogical experimental urban research. SOURCE: AUTHOR

the interplay between established theoretical assumptions, a research question, which leads to a research strategy, and the eventual reporting on the outcomes of the research. Fundamentally, such work is driven by a desire to figure out what should be done to 'solve' and engage the problem at the core of the research question. However, instead of adopting muscular explanatory theories that have fixed the structural determinants of the problem, this approach is interested in foregrounding the range of possible actions with an eye to what might work in the entangled messiness of the real city.

Actions are tabulated in two columns: probable future directions versus possible future directions. Critical social scientists are very well trained in probability. We can offer long lists of why the status quo is likely to remain stubbornly in place, and the more our outlooks are shaped by structural ontologies, the more we are trapped by probable horizons. In contrast, actions in the possible futures column are adopted by actors who are willing to take a couple of leaps of faith, believers as they are in the potential of surprise, contingency and new conjunctures that trigger unexpected cultural affects. Those who struggle to leave the land of the probable tend to conclude that the only worthy next step is confrontational political action, which in turn requires more theoretical fuel to keep the critical thought project alive.

The 'romantics', on the other hand, for lack of a better term, are keen to enter experimental labs, sites and milieus with a diversity of practitioners invested in the issues at the core of the research question (Swilling et al., forthcoming). This cohort is fated to learn how to conduct translational research - a practice 
of intermediating between different knowledge registers in order to move between science and experience, codified knowledge and tacit understanding, abstracted ideas and experientially based insights, and so on (Parnell and Pieterse, 2016). However, to achieve genuinely novel and surprising insights, these different registers need to be animated by various learning techniques that are able to surface and articulate both reasoned and affective rationalities. If done well, if curated with care, if underpinned with rigorous scholarship and commitment to social justice, these experimental labs can produce genuine innovation with regard to how to understand specific problems and/or new ways of tackling them (Simone and Pieterse, 2017).

At all times in these experimental milieus the goal is to figure out how to institutionalise novel approaches that can have material effects that will, over time, and through learning, impact on large numbers of people. The core drive of experimental milieus is to figure out what has a chance of succeeding and how the innovation can be scaled and sustained through the routine functioning of democratic institutions. In some cases, the experiments may be too modest or narrow to translate into institutional propositions. In such instances, the search moves to theorisation-raising new questions that can challenge and stretch the theoretical accounts of what might or might not work in a given situation. Both the practice of institutionalisation across differences and theoretical spadework contribute, ultimately, to deep learning. Such learning has to be embedded in the cultural aspirations of social and knowledge actors invested in figuring out an urban politics that excites, animates and instigates transformational political acts.

A core argument of this chapter is that we are in the midst of a number of important policy discursive shifts that will trigger the establishment of new urban governance mechanisms and processes. It is important to pay attention to these processes and not assume a priori that they are simply more of the same. Instead, we need to offer a critical perspective on why these institutional proposals are not simply about technocratic competence but rather a different kind of politics that needs researchers to identify and analyse the ways in which vested interests and hidden dynamics of power operate to frustrate infrastructural modernisation and democratisation. Thus, this is not an argument for only conducting research linked to institutional experimentation that must supplant conventional scholarship. On the contrary, we need a lot more interdisciplinary analysis of political institutions, lifeworlds and culture 
across the visible and hidden dimensions of politics that shape urban life and opportunity. This is especially important at a time when investments in the built environment are increasing, with profound spatial effects. However, I do think that the established academic research approaches and theoretical frameworks can be enriched and expanded if there is more articulation with localised practices of speculative research. In my reading, both traditional academic research and applied speculative exploration are essential to make sense of the new kinds of cultural-political-institutional configurations that are emerging in order to substantiate new normative commitments and aspirations. By paying attention to the multilayered nature of these contradictory processes, explicated in this chapter, we might yet have something useful to contribute to a new African urban politics and imagination.

\section{Acknowledgements}

I am grateful to the organisers of the 7th European Conference on African Studies (ECAS 2017) at the University of Basel for inviting me to present a version of this paper as a keynote address. I am also grateful for the review comments and continuous discussions with my colleagues, Sue Parnell, Anton Cartwright, Gareth Haysom, Sylvia Croese and Kim Gurney. I am solely responsible for the argument presented here. My research is supported by the National Research Foundation of South Africa.

\section{References}

Adesoji, A. (2016) 'The New Pentecostal Movement in Nigeria and the Politics of Belonging', Journal of Asian and African Studies, pp. 1-15, DOI: 10.1177/0021909616649209.

African Union (2015) Agenda 2063. The Africa We Want. Popular version, second edition. (Addis Ababa: African Union).

Amin, A. and N. Thrift (2013) Arts of the Political: New Openings for the Left (Durham, N.C.: Duke University Press).

Bayat, A. (2010) Life as Politics: How Ordinary People Change the Middle East (Stanford, CA: Stanford University Press).

Cartwright, A. (2015) Better Growth, Better Cities. Rethinking and Redirecting Urbanisation in Africa. (London: New Climate Economy), http://2015.newclimateeconomy .report/wp-content/uploads/2015/og/NCE-APP-final.pdf (accessed on 19 June 2016).

Castells, M. and P. Himanen (2014) Reconceptualizing Development in the Global Information Age (Oxford: Oxford University Press). 
Connolly, W. (2014) 'Freedom, teleodynamism, creativity', Foucault Studies, 17, pp. $60-75$.

Davis, M. (2006) Planet of the Slums (London: Verso).

Duncan, A. and G. Williams (2012) 'Making Development Assistance More Effective Through Using Political-economy Analysis: What Has Been Done and What Have We Learned?', Development Policy Review, 30, pp. 133-148, DOI: 10.1111/j.14677679.2012.00568.x.

Ferguson, J. (2011) 'Toward a left art of government: from "Foucauldian critique" to Foucauldian politics', History of the Human Sciences, 24, pp. 61-68, DOI: 10.1177/ $095^{2695111413849 .}$

Flyvbjerg, B. (2001) Making social science matter: Why social inquiry fails and how it can succeed again (Cambridge: Cambridge University Press).

Gaventa, J. (2013) 'Understanding the power cube and related concepts' in Power Pack. Understanding Power for Social Change (Brighton: Institute of Development Studies, University of Sussex).

Harris, A. and S. Moore (2013) 'Planning Histories and Practices of Circulating Urban Knowledge', International Journal of Urban and Regional Research, 37(5), 1499-1510, DOI: $10.1111 / 1468-2427.12043$.

Healey, P. (2004) ‘Creativity and Urban Governance', Policy Studies, 25, pp. 87-102, DOI: 10.1080/0144287042000262189.

Honwana, A. (2012) The time of youth: Work, social change and politics in Africa. (Washington DC: Kumarian Press).

Hyman, K. and E. Pieterse (2017) 'Infrastructure deficits and potential in African Cities' in R. Burdett, and S. Hall (eds.) The SAGE Handbook of Urban Sociology: New approaches to the twenty-first century city (London: Sage Publishers), pp. 429-451.

Jaglin, S. (2014) 'Regulating service delivery in Southern cities: rethinking urban heterogeneity' in S. Parnell and S. Oldfied (eds.) The Routledge Handbook on Cities of the Global South (London and New York: Routledge), pp. 434-447.

Kelsall, T. (2016) Thinking and working with political settlements (London: ODI).

Larkin, B. (2013) 'The politics and poetics of infrastructure', Annual Review of Anthropology, 42, pp. 327-343, DOI: 10.1146/annurev-anthro-092412-155522.

Mason, P. (2015) Postcapitalism: A Guide to our Future (London: Penguin).

Mbembe, A. (2016) 'Africa in the new century' Cityscapes, 7, pp. 51-58, https://www .cityscapesdigital.net/2015/12/og/africa-new-century/ (accessed on 23 May 2018).

Mbembe, A. (2001) On the Postcolony (Berkeley and Los Angeles: University of California Press).

McKinsey Global Institute (2016) Lions on the move II: Realizing the potential of Africa's economies (New York: McKinsey \& Company).

Miller, V., L. VeneKlasen, M. Reilly and C. Clark (2006) Making change happen: Concepts for Revisioning Power for Justice, Equality and Peace, (Washington D.C.: Just Associates). 
Miraftab, F. (2004) 'Making neo-liberal governance: the disempowering work of empowerment', International Planning Studies, 9, pp. 239-259, DOI: 10.1080/ 13563470500050130 .

Myers, G. (2011) African Cities: Alternative Visions of Urban Theory and Practice (London: Zed Books).

Naim, M. (2013) The End of Power: From Boardrooms to Battlefields and Churches to States, Why Being In Charge Isn't What It Used To Be (New York: Basic Books).

Obeng-Odoom, F. (2015) Africa: On the rise, but to where? Forum for Social Economics, 44, pp. 234-250.

OECD, AfDB and UNDP (2016) African Economic Outlook 2016. Sustainable Cities and Structural Transformation (Paris: OECD).

Parnell, S. (2016) 'Defining a global urban development agenda', World Development, 78 , pp. 529-540, DOI: 10.1016/j.worlddev.2015.10.028.

Parnell, S. and E. Pieterse (2016) 'Translational global praxis—rethinking methods and modes of African urban research', International Journal of Urban and Regional Research, 40, pp. 236-246, DOI: 10.1111/1468-2427.12278.

Pettit, J. (2013) Power analysis. A practical guide (Stockholm: SIDA).

Pieterse, E. (2008) City Futures: Confronting the Crisis of Urban Development (London and New York: Zed Books).

Pieterse, E. (2005) 'Transgressing the Limits of Possibility: Working Notes on a Relational Model of Urban Politics' in A. Simone, and A. Abouhani, (eds.) Urban Processes and Change in Africa (London: Zed Books).

Pieterse, E. and K. Hyman (2014) 'Disjunctures between urban infrastructure, finance and affordability', in S. Parnell and S. Oldfield (eds.) The Routledge Handbook on Cities of the Global South (London: Routledge).

Pieterse, E., S. Parnell and S. Croese (2017) The 2030 Agenda: Sustainable Urbanisation and the Research-Policy Interface - Issues for The G2o (Bonn: GIZ (Deutsche Gesellschaft für Internationale Zusammenarbeit)).

Platteau, J-P. (2004) 'Monitoring Elite Capture in Community-Driven Development', Development and Change, 35, pp. 223-246, DOI: 10.1111/j.1467-7660.2004.00350.x.

PwC (PricewaterhouseCoopers) (2015) Into Africa: The continent's Cities of Opportunity (Johannesburg: PwC).

Rakodi, C. (2002) 'Order and disorder in African cities: governance, politics, and urban land development processes', in O. Enwezor, U.M. Bauer, S. Ghez, S. Maharaj, M. Nash and O. Zaya (eds.) Under Siege: Four African Cities. Freetown, Johannesburg, Kinshasa, Lagos (Berlin: Hatje Cantz).

Rakodi, C. (2014) 'Religion and social life in African cities', in S. Parnell and E. Pieterse (eds.) African's Urban Revolution (London: Zed Books), pp. 82-109. 
RSA (Republic of South Africa) (2016) Integrated Development Urban Framework (Pretoria: Department of Cooperative Governance and Traditional Affairs).

Resnick, D. (2012) 'Opposition Parties and the Urban Poor in African Democracies', Comparative Political Studies, 45(11), pp. 1351-1378, DOI: 10.1177/0010414012437166.

Roe, E. (1993) 'Against power: For the politics of complexity', Transitions, 62, pp. 90-104. Scoones, I, M. Leach and P. Newell (eds) (2015) The Politics of Green Transformations (London: Routledge).

Simone, A.M. and E. Pieterse (2017) New Urban Worlds. Inhabiting Dissonant Times. (Cambridge: Polity Press).

Srnicek, N. and A. Williams (2015) Inventing the Future: Postcapitalism and a World without Work (London: Verso).

Stren, R. (2014) 'Urban Service Delivery in Africa and the Role of International Assistance', Development Policy Review, 32(S1), pp. 19-37.

Swilling, M. (2016) 'Towards Sustainable Urban Infrastructures for the Urban Anthropocene', in A. Allen, A. Lampis and M. Swilling (eds.) Untamed Urbanism. (London and New York: Routledge), pp. 19-32.

Swilling, M. (2013) 'Economic Crisis, Long Waves and the Sustainability Transition: An African Perspective', Environmental Innovations and Societal Transitions, 6, pp. 95-115, DOI: 10.1016/j.eist.2012.11.001.

Swilling, M. and E. Annecke (2012) Just Transitions: Explorations of Sustainability in an Unfair World (Cape Town and Tokyo: UCT Press and United Nations University Press).

Swilling, M., E. Pieterse and M. Hajer (forthcoming) 'Futuring, experimentation and transformative urban politics', in R. Poli (ed.) Handbook of Anticipatory Systems (New York: Springer).

Thieme, T. (2017) 'The hustle economy: Informality, uncertainty and the geographies of getting by', Progress in Human Geography, DOI: 10.1177/0309132517690039.

UNECA (United Nations Economic Commission for Africa) (2017) Economic Report 2017: Urbanization and Industrialization for Africa's Transformation, (Addis Ababa: UNECA).

UNECA (2016) Economic Report 2016: Greening Africa's Industralization (Addis Ababa: UNECA).

UNECA (2015) Economic Report on Africa 2015: Industrializing Through Trade (Addis Ababa: UNECA).

UN-Habitat (2016) World Cities Report 2016. Urbanization and Development: Emerging Futures (Nairobi: UN-Habitat).

UN-Habitat (2014) State of African Cities Report 2014. Re-imagining sustainable urban transitions (Nairobi: UN-Habitat). 
UN-Habitat and UNECA (2015) Towards an African Urban Agenda (Nairobi: UNHabitat).

UCLG (United Cities and Local Government) (2016) Co-Creating the Urban Future: The Agenda of Metropolises, Cities and Territories, Fourth Global Report on Decentralization and Local Democracy (Barcelona: UCLG).

United Nations (2015) Transforming our world: the 2030 Agenda for Sustainable Development (New York: UN Publications). 